\title{
Interferensi Bahasa Ibu Oleh Guru dan Implikasinya Terhadap Bahasa Indonesia di SMP Negeri 13 Manado
}

\author{
Sylvia Ivone Kumaat \\ Garryn Christian Ranuntu \\ Rina Pamantung \\ Pascasarjana Unsrat
}

\begin{abstract}
Language changes according to the influence of historical, psychological, social and cultural ( Hickerson 1980 : 5 ). Universality and diversity of language variation in terms of characteristics and functions of language can be observed in the school as an official institution in the field of education that organizes the learling process is considered as a small speech community or public education. As we know, school is a gathering place speakers who come from various backgrounds and different cultural communities. When the situation and conditions is the social interaction associated with the culture of each individual in the school, it appears that the communication that includes similarities and differences in the expression of speech of each individual. The core prolem in this reseach is the analysis the forms and causes interference language used by the teacher during the learning process takes place. The aims of this reseach were : identify and analyze the forms of interference mother language used by teacher.
\end{abstract}

\section{Pendahuluan}

Bahasa mempunyai sistem dan subsistem yang dipahami oleh semua penutur bahasa itu, namun karena bahasa berada pada masyarakat tutur yang merupakan kelompok manusia yang hetrogen, maka wujud bahasa yang konkret menjadi tidak seragam. Bahasa adalah sistem dari pembelajaran prilaku yang ditransmisi dari generasi ke generasi. Sebagaimana sistem budaya, bahasa berubah dari waktu ke waktu dan dapat disesuaikan dengan kebutuhan dan lingkungan. Bahasa berubah sesuai dengan pengaruh sejarah, psikologis, sosial dan budaya ( Hickerson $1980: 5$ ) 
Keuniversalan dan keragaman variasi bahasa ditinjau dari ciri dan fungsi bahasa dapat dicermati pada sekolah sebagai institusi resmi dalam bidang pendidikan yang menyelenggarakan proses belajar mengajar yang dianggap sebagai masyarakat tutur kecil atau masyarakat pendidikan. Sebagaimana diketahui, sekolah merupakan tempat berkumpulnya penutur bahasa yang berasal dari berbagai kalangan atau tingkat stratifikasi sosial ekonomi dan masyarakat budaya yang berbeda. Selain itu warga dalam lingkungan sekolah yaitu guru, siswa, dan pegawai memiliki latar belakang budaya dalam hal pemerolehan bahasa pertama atau bahasa ibu yang berbeda satu sama lain.

Memang bahasa Indonesia sudah ditetapkan sebagai bahasa nasional dan bahasa pengantar di sekolah. Multibahasa terlihat nyata dalam masyarakat pendidikan yaitu Sekolah Menengah Pertama Negeri 13 di Manado. Apabila dilihat dari penggunaan bahasa, maka posisi bahasa lain seperti bahasa asing dan bahasa daerah atau dialek bahasa daerah setempat menjadi bahasa tidak resmi dalam sekolah. Akibatnya pada komunikasi antarwarga di lingkungan sekolah terjadi pemakaian bahasa dengan berbagai variasi bahasa khususnya ragam bahasa yang dimiliki oleh warga di sekolah.

Diasumsikan bahwa sejumlah guru akan terinterferensi dengan dialek bahasa yang dimiliki dan dikuasainya, demikian juga dengan siswa. Penelitian ini hanya terfokus pada pemakaian bahasa pada guru yang mengajarkan meteri pelajaran di kelas. Sebenarnya pengaruh dari siswa terhadap pemakaian bahasa guru juga ada, yang menonjol yaitu pengaruh bahasa ibu dari guru tersebut.

Adanya penyimpangan bahasa dapat mengakibatkan terjadinya kontak bahasa yang merupakan gejala awal interferensi. Interferensi merupakan fenomena penyimpangan kaidah kebahasaan yang terjadi akibat seseorang menguasai dua bahasa atau lebih. Suwito ( 1983 : 54 ) berpendapat bahwa interferensi sebagai penyimpangan karena unsur yang diserap oleh 
sebuah bahasa sudah ada padanannya dalam bahasa penyerap. Jadi manifestasi penyebab terjadinya interferensi adalah kemampuan penutur dalam menggunakan bahasa tertentu.

Berdasarkan pada asumsi yang sudah dikemukakan di atas maka penelitian tentang ragam bahasa ibu dari guru di SMP Negeri 13 perlu dilakukan secara mendalam untuk melihat bahasa apa saja yang termasuk pada jenis bahasa ibu yang dipakai oleh guru pada proses belajar mengajar di sekolah.

\section{Perumusan masalah}

Berdasarkan latar belakang pemikiran di atas, maka yang menjadi permasalahan dalam penelitian ini yaitu : Apa saja faktor yang menyebabkan guru menggunakan bahasa ibu dalam proses belajar mengajar di sekolah ?

\section{Tujuan Penelitian}

Penelitian ini bertujuan untuk mengetahui faktor penyebab guru menggunakan bahasa ibu dalam proses belajar mengajar di sekolah

\section{Tinjauan Pustaka}

Penelitian yang dilakukan oleh Senduk (2009) yang meneliti tentang pengaruh faktorfaktor sosiolinguistis terhadap penggunaan bahasa guru dalam proses belajar mengajar bahasa Indonesia. Secara umum penelitian ini bertujuan untuk memperoleh gambaran tentang penggunaan bahasa guru di beberapa SMA di kota Manado dalam proses belajar mengajar bahasa Indonesia serta faktor-faktor sosiolinguistis yang mempengaruhi penggunaan bahasa Indonesia. Dalam penelitian ini perhatian dipusatkan pada kontak yang terjadi antara bahasa Indonesia dan bahasa Melayu Manado dalam masyarakat guru sebagai penutur-penutur yang 
bilingual dalam kedua bahasa tersebut. Sedangkan penelitian yang akan dilakukan fokusnya pada guru yang mengajar mata pelajaran IPS, PKN, dan bahasa Indonesia.

Dari beberapa penelitian yang diuraikan di atas ada berbagai permasalahan yang diangkat berkaitan dengan ragam bahasa. Akan tetapi, penelitian ini akan menguraikan tentang penggunaan bahasa ibu oleh guru dalam proses belajar mengajar di SMP Negeri 13 Manado.

\section{Pengertian Interferensi}

Adanya penyimpangan bahasa dapat mengakibatkan terjadinya kontak bahasa yang merupakan gejala awal interferensi.

Istilah interferensi pertama kali digunakan oleh Weinreich (1953) untuk menyebut adanya perubahan sistem suatu bahasa sehubungan dengan adanya persentuhan bahasa tersebut dengan unsur-unsur bahasa lain yang dilakukan oleh penutur yang bilingual. Penutur yang bilingual adalah penutur yang menggunakan dua bahasa secara bergantian. Namun kemampuan setiap penutur terhadap B1 dan B2 sangat bervariasi. Ada penutur yang menguasai B1 dan B2 sama baiknya, tapi ada pula yang tidak, malahan ada yang kemampuannya terhadap B2 sangat minim. Penutur bilingual yang mempunyai kemampuan terhadap B1 dan B2 sama baiknya tentu tidak mempunyai kesulitan untuk menggunakan bahasa itu kapan saja diperlukan, karena tindak laku kedua bahasa itu terpisah dan bekerja sendiri-sendiri.

Interferensi merupakan fenomena penyimpangan kaidah kebahasaan yang terjadi akibat seseorang menguasai dua bahasa atau lebih. Suwito (1983 : 54) berpendapat bahwa interferensi sebagai penyimpangan karena unsur yang diserap oleh sebuh bahasa sudah ada padanannya dalam bahasa penyerap. Jadi manifestasi penyebab terjadinya interferensi adalah kemampuan penutur dalam menggunakan bahasa tertentu. 


\section{Metode Penelitian}

Metode yang digunakan dalam penelitian ini ialah metode deskriptif kualitatif. Penelitian deskriptif mencoba mencari deskripsi yang dapat dicakup dari semua aktivitas, objek, proses dan manusia (Sulistyo, 2006 :110). Pendekatan deskriptif dirancang untuk memperoleh informasi tentang status suatu gejala pada saat penelitian dilakukan dan tidak diupayakan memberikan suatu perlakuan. Metode kualitatif merupakan prosedur penelitian yang mengahasilkan data deskriptif berupa kata-kata tertulis atau lisan dari orang-orang dan prilaku yang dapat diamati (Bogdan dan Taylor dalam Moleong, 1989 :3).

Metode deskriptif kualitatif yang digunakan dalam penelitian ini dimaksudkan untuk mendeskripsikan aktivitas tutur pada saat guru mengajar. Aktifitas tutur yang dimaksud adalah kata-kata yang dituturkan secara

\section{Hasil Penelitian}

Sebelum seseorang menguasai dua bahasa atau lebih yang pertama kali memengaruhi mendasari bahasa seseorang umumnya adalah bahasa ibu. Bahasa ibu yang merupakan bahasa pertama biasanya diperoleh dalam lingkungan keluarga atau masyarakat. Kecenderungan pemakaian bahasa ibu atau bahasa pertama sangat tergantung pada bahasa yang paling dominan dipergunakan ditengah-tengah masyarakat. Hal ini terbukti karena bahasa ibu lebih sering digunakan bila dibandingkan dengan bahasa Indonesia. Dengan demikian kita tidak heran bila bahasa ibu akan memengaruhi penggunaan bahasa Indonesia penuturnya .

Demikian pula yang terjadi dalam proses belajar di sekolah, berdasarkan hasil penelitian guru menggunakan bahasa ibu ketika memberikan pertanyaan, penegasan penjelasan materi, menegur siswa, memberi pujian pada siswa atas jawaban dari pertanyaan yang diberikan, memberikan penjelasan materi dan meminta perhatian siswa. Sama halnya 
juga dengan guru yang lain mengatakan bahwa penggunaan bahasa ibu dilakukan dengan tujuan :

1. Menegur atau memarahi siswa yang tidak mengikuti pelajaran dengan baik

2. Menyuruh siswa melakukan suatu pekerjaan

3. Bertanya kepada siswa

4. Meminta perhatian pada siswa

5. Memberi contoh atau memperjelas bahan pelajaran yang sedang diberikan

6. Ada juga yang tanpa sadar telah menggunakan bahasa ibu karena bahasa ibu sangat melekat dalam pribadi guru tersebut.

Sebagai contoh dalam sebuah kegiatan proses belajar di kelas seorang guru dalam mejelaskan materi pelajaran menggunakan bahasa Indonesia yang baik dan benar sudah barang tentu dapat dipahami oleh siswa tetapi apabila warga kelasnya atau siswanya sudah terbiasa menggunakan bahasa Indonesia yang baik dan benar. Sebaliknya sebagai anak peserta didik atau siswa tetap terbiasa menggunakan bahasa pertama yang juga sering disebut sebagai bahasa ibu dalam komunikasi di lingkungan formal maka sangat sulit bagi guru menggunakan bahasa Indonesia sebagai bahasa pengantar dalam menyampaikan materi pelajaran dalam dunia pendidikan. Begitu pula apabila guru dan siswa sebagai peserta didik selalu menggunakan bahasa ibu sebagai pengantar pendidikan maka tidak mengherankan bila penguasaan bahasa Indonesia yang baik saja yang dikuasai oleh siswa dan guru. Sementara itu keberadaan bahasa Indonesia yang baik dan benar yang menjadi tuntutan sebagai komunikasi formal atau resmi akan dikesampingkan.

Ada juga penggunaan bahasa ibu ketika guru bertanya kepada siswa.

Contoh : So mangarti? 
Sudah mengerti ?

Ada yang mo ba tanya?

Ada yang ingin bertanya?

So beking?

Sudah di buat?

Io toh?

(menegaskan suatu pernyataan / jawaban )

Blum pernah?

Belum pernah ?

Ada lupa bawa ato nyanda beking ?

Apakah lupa di bawa atau tidak di buat?

Kiyapa blong klar?

Kenapa tidak selesai ?

Contoh berikut ini tentang penggunaan bahasa ibu oleh guru ketika meminta perhatian dari siswa .

Contoh : $\quad$ Tarokira kamari dulu

Perhatikan guru menjelaskan

Tara mo dengar?

Tidak mau mendengar? 


\section{Lia kamari!}

Perhatikan kasini !

So mangarti?

Sudah mengerti ?

Brenti ba cerita!

Berhenti bercakap-cakap!

\section{Pembahasan}

Hasil temuan bentuk-bentuk interferensi bahasa ibu oleh guru dalam proses belajar mengajar di kelas dan impikasinya terhadap bahasa Indonesia di SMP Negeri 13 Manado, selanjutnya dibahas untuk menjawab permasalahan dalam penelitian ini yaitu :

1. Bentu-bentuk interferensi bahasa ibu oleh guru dalam proses belajar di SMP Negeri 13 Manado.

Seperti yang telah dijelaskan dalam bab kerangka teoretis, interferensi merupakan fenomena penyimpangan kaidah kebahasaan yang terjadi akibat seseorang mengusai dua bahasa atau lebih. Suwito ( $1983: 54$ ) berpendapat bahwa interferensi sebagai penyimpangan karena unsur yang diserap oleh sebuah bahasa sudah ada padanannya dalam bahasa penyerap. Contoh somo ( menggambarkan kejadian atau perbuatan yang baru akan dimulai / terjadi ) padanannya dalam bahasa Indonesia sudah mau / sudah akan. Akan tetapi dalam hasil penelitian ini juga ditemukan interferensi yang terjadi karena adanya pertukaran bentuk kata ganti orang, seperti : kita, ngana, ngoni, torang dalam bahasa Indonesia seharusnya saya, anda / kamu, kalian, kita. Ada juga interferensi yang terjadi karena adanya penghapusan atau penghilangan fonem. Contoh : kalo, jang, nda, ato, so, lia, deng, kong, mo yang seharusnya kalau, jangan, tidak, atau, sudah, lihat, dengan, kemudian, akan. Hal ini 
memperkuat pernyataan dari Hortman dan Stork melalui Alwasilah ( 1985 : 131 ) yang menyatakan bahwa interferensi sebagai kekeliruan yang disebabkan oleh terbawanya kebiasaan-kebiasaan ujaran bahasa atau dialek bahasa ibu ke dalam bahasa atau dialek ke dua. Artinya interferensi merupakan kekeliruan yang disebabkan oleh adanya kecenderungan membiasakan pengucapan ( ujaran ) suatu bahasa terhadap bahasa lain, mencakup pengucapan satuan bunyi, tata bahasa dan kosakata.

2. Faktor penyebab guru menggunakan bahasa ibu

Bahasa ibu yang merupakan bahasa pertama biasanya diperoleh dalam lingkungan keluarga atau masyarakat. Kecenderungan pemakaian bahasa ibu atau bahasa pertama sangat tergantung pada bahasa yang paling dominan dipergunakan di tengah-tengah masyarakat.

Demikian pula yang terjadi dalam proses belajar di sekolah, berdasarkan hasil penelitian guru menggunakan bahasa ibu ketika memberikan pertanyaan contoh : sapa yang blum pernah dengar tentang koropsi ? , menegaskan penjelasan materi contoh : Dorang musti ada ide kreatip deng inovatip, menegur siswa contoh : bekeng skarang !, memberi pujian pada siswa contoh butul skali, meminta perhatian siswa contoh : co tarokira kamari dulu !. Sama halnya juga dengan guru yang lain yang mengatakan bahwa penggunaan bahasa ibu dilakukan dengan tujuan :

1. Menegur atau memarahi siswa yang tidak mengikuti pelajaran dengan baik

2. Menyuruh siswa melakukan suatu pekerjaan

3. Bertanya kepada siswa

4. Meminta perhatian pada siswa

5. Memberi contoh atau memperjelas bahan pelajaran yang sedang diberikan

6. Ada juga yang tanpa sadar telah menggunakan bahasa ibu karena bahasa ibu sangat melekat dalam pribadi guru tersebut. 
Guru memegang peranan yang penting dalam usaha peningkatan mutu dan disiplin penggunaan bahasa Indonesia yang baik dan benar di kalangan siswa dapat diharapkan berhasil hanya apabila guru sendiri menunjukkan adanya kesanggupan menggunakan bahasa Indonesia dengan baik dan benar, bermutu dan berdisiplin. Guru di samping berfungsi sebagai penyaji ilmu pengetahuan juga berfungsi sebagai teladan bagi siswa-siswanya. I Gusti Ngurah Oka (Halim, 1984:61) menambahkan "sikap mental positif terhadap bahasa Indonesia, siswa dan pengajaran bahasa Indonesia yang harus pula dimiliki oleh seorang guru. Oleh karena sekolah merupakan suatu lingkungan yang harus memfungsikan ragam bahasa Indonesia baku, maka guru-guru tidak ada pilihan lain kecuali harus mengajarkan dan menggunakan bahasa Indonesia yang baik dan benar.

\section{Simpulan}

Berdasarkan hasil dan pembahasan yang telah diuraikan pada bab sebelumnya, dan mengacu pada inti permasalahan dalam penelitian ini, maka dikemukakan beberapa kesimpulan sebagai berikut :

1. Bentuk-bentuk interferensi bahasa ibu yang digunakan oleh guru dalam proses belajar mengajar di SMP Negeri 13 Manado.

a. Interferensi yang terjadi karena penyimpangan kaidah kebahasaan karena seseorang menguasai dua bahasa atau lebih.

Contoh : somo ---------sudah mau / sudah akan

b. Interferensi yang terjadi karena adanya pertukaran bentuk kata ganti orang. Contoh : kita, ngana, ngoni, torang--------- saya, anda / kamu, kalian.

c. Ada juga interferensi yang terjadi karena adanya penghapusan atau penghilangan fonem tertentu. 
Contoh : kalo, jang, nda, ato, so, lia, deng, kong, mo.--------kalau, jangan, tidak, atau, sudah, lihat, dengan, kemudian, akan.

2. Faktor penyebab guru menggunakan bahasa ibu

Berdasarkan hasil penelitian guru menggunakan bahasa ibu ketika :

a. Menegur atau memarahi siswa yang tidak mengikuti pelajaran dengan baik

b. Menyuruh siswa melakukan suatu pekerjaan

c. Bertanya kepada siswa

d. Meminta perhatian pada siswa

e. Memberi contoh atau memperjelas bahan pelajaran yang sedang diberikan

f. Ada juga yang tanpa sadar telah menggunakan bahasa ibu karena bahasa ibu sangat melekat dalam pribadi guru tersebut.

3. Bahasa Indonesia baku hampir tidak digunakan dalam interaksi belajar mengajar di sekolah. Padahal menggunakan bahasa Indonesia yang baik dan benar merupakan tuntutan bagi guru, bahkan menghindarkan pengaruh bahasa ibu, bahasa daerah yang mengganggunya dalam kegiatan bertutur bahasa Indonesia. Sikap positif terhadap bahasa Indonesia dan penggunaannya dituntut pula dari seorang guru yang selalu dijadikan contoh dan teladan bagi anak didiknya.

Dengan keadaan penggunaan bahasa yang beragam dalam kenyataan sehari-hari, semakin terasa pentingnya peranan bahasa yang digunakan oleh guru. Bagi siswa-siswa yang oleh karena lingkungannya lebih banyak menggunakan bahasa ibu atau bahasa daerah mereka, bahasa yang digunakan oleh guru adalah contoh nyata bahasa Indonesia. Gurulah yang menjadi tokoh kaitan bahasa Indonesia yang mencerminkan kaidah-kaidah yang baik.

Walaupun usaha menggunakan bahasa Indonesia sebagai bahasa pengantar selalu ada, guru-guru tersebut selalu menggunakan bahasa ibu di kelas untuk tujuan-tujuan tertentu. Jadi tidak sepenuhnya bahasa Indonesia dapat digunakan sebagai bahasa pengantar di kelas. 
Bahasa Indonesia dan bahasa ibu diselang-seling penggunaannya. Suasana kelas yang ada, topik yang sedang dibicarakan, tujuan yang akan dicapai, dan siswa yang dihadapi merupakan unsur-unsur yang menentukan apakah bahasa Indonesia atau bahasa ibu yang harus digunakan. Dalam kaitan dengan pengertian tersebut, tidaklah berarti bahwa bahasa ibulah yang harus ditonjolkan penggunaannya.

Di satu sisi penggunaan bahasa ibu sangat menguntungkan bagi penutur dan petutur. Dari segi sosiolinguistik itu dibenarkan karena dalam kajian sosiolinguistik belajar mengenai kontak bahasa. Di mana ada dua atau lebih bahasa yang dikuasai dalam satu wilayah pasti terjadi variasi bahasa. Di sekolah ketika pemakai bahasa menguasai dua bahasa dalam hal ini bahasa ibu dan bahasa Indonesia jelas penggunaan bahasa ibu akan secara sadar maupun tidak sadar akan terjadi. Bisa dikatakan menarik karena siswa lebih mudah memahami materi yang diajarkan dengan menggunakan bahasa ibu. Faktor kebiasaan menggunakan bahasa ibu menyebabkan mereka tidak dapat melepaskan diri dari pengaruh bahasa ibu pada waktu mereka seharusnya menggunakan bahasa Indonesia di kelas. Adanya kemiripan antara bahasa ibu (khususnya di Sulawesi) dengan bahasa Indonesia merupakan faktor yang berpengaruh pula.

\section{DAFTAR PUSTAKA}

Badudu, J.S. 1985. Pelik-pelik Bahasa Indonesia. Bandung : Pustaka Prima.

Bawa, I. W dan I Wayan Cika.2004. Bahasa dalam Perspektif Kebudayaan. Denpasar: Universitas Udayana.

Bloomfield, L. 1933. Language, Terjemahan Sutikno. 1995. Bahasa. Jakarta: PT Gramedia.

Brown, H. D. 2007. Prinsip Pembelajaran Dan Pengajaran Bahasa.Jakarta. Pearson Education.

Chaer, A. 1994. Linguistik Umum. Jakarta : P.T Rineka Cipta.

Chaer, A. 1995.Hubungan Bahasa, Kebudayaan, dan Pemikiran. Dewan Bahasa : Jilid 2

Chaer,A. 2004. Sosiolinguistik. Perkenalan Awal. Jakarta: Rineka Cipta.

Hickerson. 1980.

Jendra I wayan. 1984 a. Dasar-dasar Sosiolinguistik. Denpasar: Ikayana

Jendra I Wayan.1984 b. Kedwibahasaan Alih Kode, Proyek Peningkatan dan Pengembangan Perguruan Tinggi (P3T). Denpasar : Universitas Udayana.

Kridalaksana, Harimurti. 1988. Beberapa Prinsip Perpaduan Leksem dalam Bahasa Indonesia. Yokyakarta: Kanisius.

Kridalaksana, Harimurti.1994. Kelas Kata dalam Bahasa Indonesia. Jakarta: Gramedia. 